\title{
Feraequornithes: a name for the clade formed by Procellarii- formes, Sphenisciformes, Ciconiiformes, Suliformes and Pelecaniformes (Aves)
}

\author{
George Sangster ${ }^{1}$, Gerald Mayr ${ }^{2}$ \\ 1 Naturalis Biodiversity Center, Darwinweg 2, PO Box 9517, 2300 RA Leiden, The Netherlands \\ 2 Ornithological Section, Senckenberg Research Institute and Natural History Museum Frankfurt, Frankfurt am Main, Germany \\ http://zoobank.org/9AF3A88B-864D-4996-B0D9-1797B59A1B9A \\ Corresponding author: George Sangster (g.sangster@planet.nl)
}

Academic editor Martin Päckert ｜ Received 25 September $2020 \quad$ Accepted 21 December $2020 \quad$ Published 2 March 2021

Citation: Sangster G, Mayr G (2021) Feraequornithes: a name for the clade formed by Procellariiformes, Sphenisciformes, Ciconiiformes, Suliformes and Pelecaniformes (Aves). Vertebrate Zoology 71: 49-53. https://doi.org/10.3897/vz.71.e61728

\begin{abstract}
Recent genomic data sets have resolved many aspects of higher-level phylogenetic relationships of birds. Eleven phylogenomic studies provide congruent support for a clade formed by Procellariiformes, Sphenisciformes, Ciconiiformes, Suliformes and Pelecaniformes. This clade is here named 'Feraequornithes' following the rules and requirements of the PhyloCode.
\end{abstract}

\section{Key words}

Aequornithes, clade names, PhyloCode, phylogenetic nomenclature, rankless taxonomy

\section{Introduction}

The resolution of the avian tree of life has proceeded steadily since the first use of nuclear DNA markers in avian systematics in the late $1990 \mathrm{~s}$. With the analysis of phylogenomic data sets, many aspects of higher-level relationships of birds were congruently resolved by independent data sets (Ericson et al. 2006; Hackett et al. 2008; McCormack et al. 2013; Jarvis et al. 2014; Burleigh et al. 2015; Prum et al. 2015; Reddy et al. 2017; Kuhl et al. 2021). One recently clarified group is a large clade of aquatic and semi-aquatic birds (Ericson et al. 2006; Hackett et al. 2008; Burleigh et al. 2015; Prum et al. 2015; Kimball et al. 2019; Kuhl et al. 2021), which was named Aequornithes (Mayr 2011). Aequornithes (Fig. 1) includes the divers (Gaviidae), storm-petrels (Hydrobatidae, Oceanitidae), albatrosses (Diomedeidae), petrels (Procellariidae) including diving-petrels (Pelecanoides spp.), penguins (Spheniscidae), storks (Ciconiidae), frigatebirds (Fregatidae), darters (Anhingidae), cormorants (Phalacrocoracidae), gannets and boobies (Sulidae), herons (Ardeidae), ibises (Threskiornithidae), pelicans (Pelecanidae), Shoebill (Balaenicipitidae), Hamerkop (Scopidae) and the extinct stem representatives of these clades.

These studies have further shown that 'Pelecaniformes' and 'Ciconiiformes', as traditionally circumscribed (e.g. Storer 1971; Howard and Moore 1991), represent non-monophyletic groups. There is now robust evidence that herons, ibises, pelicans and allies form a clade; that the frigatebirds, darters, cormorants, gannets and boobies form another clade, and that the storks represent a third clade. These three clades are now known as Pelecaniformes, Suliformes and Ciconiiformes, respectively (Yuri et al. 


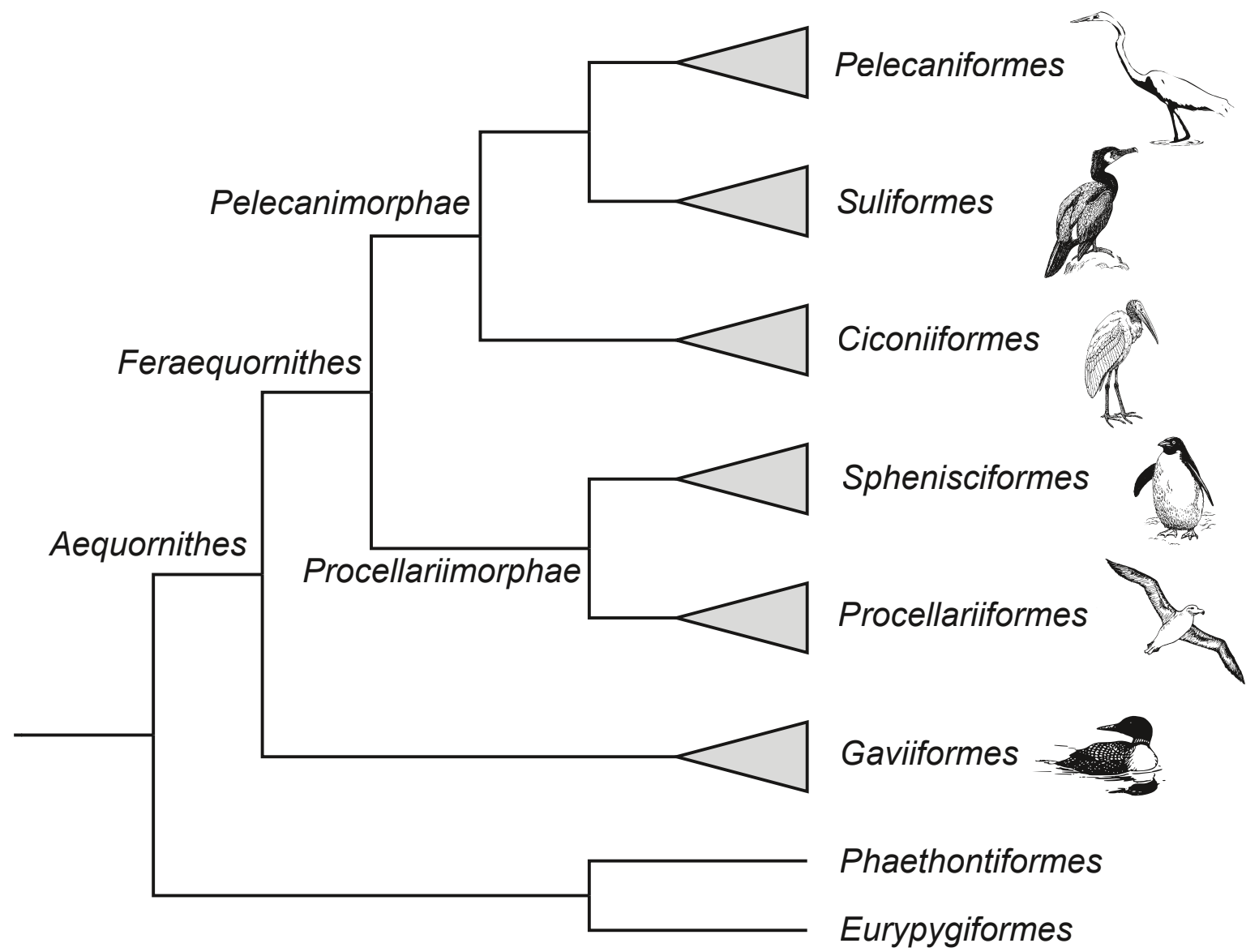

Figure 1. Consensus phylogeny of aquatic and semi-aquatic birds (based on Hackett et al. 2008, Burleigh et al. 2015, Prum et al. 2015, Reddy et al. 2017, Kimball et al. 2019, Kuhl et al. 2021). All bird vignettes are in the public domain (https://publicdomainvectors.org).

2013; Mayr 2017; Kimball et al. 2019; Kuhl et al. 2021), although Cracraft (2013) used the name Pelecaniformes for a group that combines all three clades. A sister group relationship of Procellariiformes and Sphenisciformes is also well-supported (Hackett et al. 2008; McCormack et al. 2013; Jarvis et al. 2014; Burleigh et al. 2015; Kuramoto et al. 2015; Prum et al. 2015; Reddy et al. 2017; Kimball et al. 2019; Kuhl et al. 2021), and this clade has been named Procellariimorphae (Livezey and Zusi 2007).

Evidence for a clade formed by Procellariiformes, Sphenisciformes, Ciconiiformes, Suliformes and Pelecaniformes consists of multiple phylogenomic data sets generated in eleven studies, and is summarized in Table 1. This clade has not been named yet, unlike many other novel clades that are now widely supported (Sangster 2005a, 2005b; Mayr 2011; Suh et al. 2011; Ericson 2012; Yuri et al. 2013; Prum et al. 2015).

The stability of taxonomic names above the superfamily rank has long been problematic because their availability and priority was not governed by any nomenclatural code. In the mid 1980s, taxonomists begun proposing, discussing and using phylogenetic definitions for clade names (e.g. Gauthier 1986; Rowe 1987; De Queiroz and Gauthier 1992; Bryant 1994; Lee 1996; Padian et al. 1999). This grew out of the recognition that the current rank-based systems of nomenclature (e.g. ICZN 1999) are poorly suited to regulate the names of clades. These discussions about phylogenetic nomenclature have led to the development of the PhyloCode which went through several preliminary versions that appeared online between 2000 and 2019. The publication of the PhyloCode (v6; Cantino and De Queiroz 2020), which came into effect in June 2020 with the publication of the companion volume Phylonyms (De Queiroz et al. 2020) and the RegNum online database (Cellinese and Dell 2020), now provides an opportunity to formalize and stabilize clade names. The PhyloCode provides rules for the express purpose of naming clades through explicit reference to phylogeny (Cantino and De Queiroz 2020). The purpose of this note is to define a name for the clade formed by Procellariiformes, Sphenisciformes, Ciconiiformes, Suliformes and Pelecaniformes following the rules and requirements of the PhyloCode.

\section{Feraequornithes, new clade name}

\section{RegNum registration number: 416}

Definition. The least-inclusive crown clade containing Pelecanus onocrotalus Linnaeus, 1758 (Pelecaniformes) and Procellaria aequinoctialis Linnaeus, 1758 (Procel- 
Table 1. Phylogenomic support for the clade formed by Procellariiformes, Sphenisciformes, Ciconiiformes, Suliformes and Pelecaniformes. ML, maximum likelihood; PP, posterior probability; MRP, matrix representation with parsimony; SH-aLRT, Shimodaira-Hasegawa approximate likelihood ratio test.

\begin{tabular}{|l|l|l|}
\hline Source & Data type(s) & Support \\
\hline Hackett et al. (2008) & 19 nuclear loci & $94 \%$ ML bootstrap \\
\hline McCormack et al. (2013) & 1541 ultra-conserved elements & $100 \%$ ML bootstrap; 1.0 PP \\
\hline Jarvis et al. (2014) & 8251 exon loci, 2516 intron loci, 3769 ultra-conserved elements & $100 \%$ exaML bootstrap \\
\hline Burleigh et al. (2015) & 25 nuclear loci, mitochondrial DNA & $73 \%$ ML bootstrap \\
\hline Kuramoto et al. (2015) & 30 retroposon presence/absence loci & $\mathrm{P}<0.001$ \\
\hline Prum et al. (2015) & 259 anchored nuclear loci & 1.0 PP \\
\hline Suh et al. (2015) & 2118 retroposon presence/absence loci & (not given) \\
\hline Reddy et al. (2017) & 54 nuclear loci & $\geq 95 \%$ ML bootstrap \\
\hline Liu et al. (2018) & 63 nuclear protein-coding loci & $99 \%$ ML bootstrap \\
\hline Kimball et al. (2019) & supertree & $100 \%$ MRP bootstrap \\
\hline Kuhl et al. (2021) & $\begin{array}{l}\text { noncoding 3-prime untranslated region (3'UTR) sequences } \\
(2.5 \text { million analyzable patterns) }\end{array}$ & $100 \%$ (SH-aLRT) \\
\hline
\end{tabular}

lariiformes). This is a minimum-crown-clade definition. Abbreviated definition: min crown $\nabla$ (Pelecanus onocrotalus Linnaeus, 1758 \& Procellaria aequinoctialis Linnaeus, 1758).

Etymology. Coined from a combination of Aequornithes with the Latin adverb fere, meaning "almost" or "near", in reference to the fact that the clade includes almost all Aequornithes except Gaviiformes.

Reference phylogeny. For the purpose of applying the definition of Feraequornithes, Figure 3 in Kuhl et al. (2021) should be regarded as the primary reference phylogeny. Figure 1 in Prum et al. (2015) may be regarded as a secondary reference phylogeny.

Composition. Feraequornithes includes the herons (Ardeidae), ibises (Threskiornithidae), pelicans (Pelecanidae), Shoebill (Balaenicipitidae), Hamerkop (Scopidae), frigatebirds (Fregatidae), darters (Anhingidae), cormorants (Phalacrocoracidae), gannets and boobies (Sulidae), storks (Ciconiidae), storm-petrels (Hydrobatidae, Oceanitidae), albatrosses (Diomedeidae), petrels (Procellariidae) including diving petrels (Pelecanoides spp.), and penguins (Spheniscidae). This clade comprises 310350 extant species, listings of which are given in Dickinson and Remsen, (2013) and Gill et al. (2020). Accounts of extinct groups (Diomedeoididae, Plotopteridae) are provided by Olson and Hasegawa (1979), De Pietri et al. (2010), Mayr and Smith (2012), Mayr (2017) and Mayr et al. (2021).

Diagnostic apomorphies. Members of this clade possess long, slit-like nostrils in juveniles (Mayr 2017). These are absent in extant Sphenisciformes and Procellariiformes, but occur in adults of long-beaked fossil stem group Sphenisciformes (Ksepka et al. 2008; Mayr et al. 2017). Possibly correlated with the latter trait, the beak of adult birds of most representatives of the clade exhibits furrows along its lateral surfaces, which begin at the rostral end of the nostril (these furrows are absent in the Ciconiidae and weakly developed in the Ardeidae). Kuramoto et al. (2015) listed eight apomorphic retroposons (Chicken Repeat 1 insertions), which are found on chromosomes 1 , $1 \mathrm{~A}, 2,5$ and 20.

Comment. Pelecanus onocrotalus Linnaeus, 1758 and Procellaria aequinoctialis Linnaeus, 1758 were selected as reference taxa, because these are the type species of the genera Pelecanus and Procellaria, respectively. A nodebased (minimum-crown-clade) definition was selected because there is very strong, congruent support for the basal dichotomy within Feraequornithes in recent molecular analyses (Hackett et al. 2008; McCormack et al. 2013; Jarvis et al. 2014; Burleigh et al. 2015; Kuramoto et al. 2015; Prum et al. 2015; Suh et al. 2015; Reddy et al. 2017; Kimball et al. 2019; Kuhl et al. 2021).

\section{Acknowledgements}

We are grateful to two anonymous reviewers and the associate editor, Martin Päckert, for their constructive comments on a previous draft of this manuscript.

\section{References}

Bryant HN (1994) Comments on the phylogenetic definition of taxon names and conventions regarding the naming of crown clades. Systematic Biology 43: 124-130. https://doi.org/10.2307/2413585

Burleigh JG, Kimball RT, Braun EL (2015) Building the avian tree of life using a large-scale, sparse supermatrix. Molecular Phylogenetics and Evolution 84: 53-63. https://doi.org/10.1016/j.ympev.2014.12 .003

Cantino PD, De Queiroz K (2020) International Code of Phylogenetic Nomenclature (PhyloCode). CRC Press, Boca Raton.

Cellinese N, Dell C (2020) RegNum - The international clade names repository. Available from: https://www.phyloreg-num.org (November 9, 2020)

Cracraft J (2013) Avian higher-level relationships and classification: Nonpasseriforms, pp. xxi-xliii in: Dickinson EC, Remsen JV Jr (eds) 
The Howard and Moore complete checklist of the birds of the world. Fourth edition, vol. 1: Non-passerines. Aves Press, London.

De Pietri VL, Berger J-P, Pirkenseer C, Scherler L, Mayr G (2010) New skeleton from the early Oligocene of Germany indicates a stemgroup position of diomedeoidid birds. Acta Palaeontologica Polonica 55: 23-34. https://doi.org/10.4202/app.2009.0069

De Queiroz K, Gauthier J (1992) Phylogenetic taxonomy. Annual Reviews in Ecology and Systematics 23: 449-480. https://doi.org/10. 1146/annurev.es.23.110192.002313

De Queiroz K, Cantino P, Gauthier J (eds) (2020) Phylonyms: a Companion to the PhyloCode. CRC Press, Boca Raton.

Dickinson EC, Remsen Jr JV (eds) (2013) The Howard and Moore complete checklist of the birds of the world. Fourth edition, vol. 1: Non-Passerines. Aves Press, London.

Ericson PGP (2012) Evolution of terrestrial birds in three continents: biogeography and parallel radiations. Journal of Biogeography 39: 813-824. https://doi.org/10.1111/j.1365-2699.2011.02650.x

Ericson PGP, Anderson CL, Britton T, Elzanowski A, Johansson US, Källersjö M, Ohlson JI, Parsons TJ, Zuccon D, Mayr G (2006) Diversification of Neoaves: integration of molecular sequence data and fossils. Biology Letters 2: 543-547. https://doi.org/10.1098/rsbl.2006.0523

Gauthier J (1986) Saurischian monophyly and the origin of birds. Memoirs of the California Academy of Sciences 8: 1-55.

Gill F, Donsker D, Rasmussen P (eds) (2020) IOC World Bird List (v10.2). http://www.worldbirdnames.org. https://doi.org/10.14344/ IOC.ML.10.2 [accessed 24 August 2020]

Hackett SJ, Kimball RT, Reddy S, Bowie RCK, Braun EL, Braun MJ, Chojnowski JL, Cox WA, Han K-L, Harshman J, Huddleston CJ, Marks BD, Miglia KJ, Moore WS, Sheldon FH, Steadman DW, Witt CC, Yuri T (2008) A phylogenomic study of birds reveals their evolutionary history. Science 320: 1763-1768. https://doi.org/10.1126/ science. 1157704

Howard R, Moore A (1991) A Complete Checklist of the Birds of the world. Second Edition. Academic Press, London.

International Commission on Zoological Nomenclature [ICZN] (1999) International Code of Zoological Nomenclature. The International Trust for Zoological Nomenclature, London. Available from: https:// www.iczn.org/the-code/the-international-code-of-zoological-nomenclature/the-code-online (November 9, 2020)

Jarvis ED, Mirarab S, Aberer AJ, Li B, Houde P, Li C, Ho SYW, et al. (2014) Whole-genome analyses resolve early branches in the tree of life of modern birds. Science 346: 1320-1331. https://doi.org/ 10.1126/science. 1253451

Kimball RT, Oliveros CH, Wang N, White ND, Barker FK, Field DJ, Ksepka DT, Chesser RT, Moyle RG, Braun MJ, Brumfield RT, Faircloth BC, Smith BT, Braun EL (2019) A phylogenomic supertree of birds. Diversity 11(7): 109. https://doi.org/10.3390/d11070109

Ksepka DT, Clarke JA, DeVries TJ, Urbina M (2008) Osteology of Icadyptes salasi, a giant penguin from the Eocene of Peru. Journal of Anatomy 213: 131-147. https://doi.org/10.1111/j.1469-7580.2008.00927.x

Kuhl H, Frankl-Vilches C, Bakker A, Mayr G, Nikolaus G, Boerno ST, Klages S, Timmermann B, Gahr M (2021) An unbiased molecular approach using 3'UTRs resolves the avian family-level tree of life. Molecular Biology and Evolution, 38: 108-127. https://doi.org/10. 1093/molbev/msaa191

Kuramoto T, Nishihara H, Watanabe M, Okada N (2015) Determining the position of storks on the phylogenetic tree of waterbirds by ret- roposon insertion analysis. Genome Biology and Evolution 7: 31803189. https://doi.org/10.1093/gbe/evv213

Lee MSY (1996) Stability in meaning and content of taxon names: an evaluation of crown-clade definitions. Proceedings of the Royal Society of London B 263: 1103-1109. https://doi.org/10.1098/rspb.1996.0162

Liu Y, Liu S, Yeh CF, Zhang N, Chen G, Que P, Dong L, Li SH (2018) The first set of universal nuclear protein-coding loci markers for avian phylogenetic and population genetic studies. Scientific Reports 8: 15723. https://doi.org/10.1038/s41598-018-33646-x

Livezey BC, Zusi RL (2007) Higher-order phylogeny of modern birds (Theropoda, Aves: Neornithes) based on comparative anatomy. II. Analysis and discussion. Zoological Journal of the Linnean Society 149: 1-95. https://doi.org/10.1111/j.1096-3642.2006.00293.x

Mayr G (2011) Metaves, Mirandornithes, Strisores and other novelties - a critical review of the higher-level phylogeny of neornithine birds. Journal of Zoological Systematics and Evolutionary Research 49: 58-76. https://doi.org/10.1111/j.1439-0469.2010.00586.x

Mayr G (2017) Avian Evolution: The Fossil Record of Birds and its Paleobiological Significance. Wiley-Blackwell, Chichester.

Mayr G, De Pietri VL, Love L, Mannering AA, Scofield RP (2017) A well-preserved new mid-Paleocene penguin (Aves, Sphenisciformes) from the Waipara Greensand in New Zealand. Journal of Vertebrate Paleontology 37: e1398169. https://doi.org/10.1080/02724634.2017. 1398169

Mayr G, Goedert JL, De Pietri VL, Scofield RP (2021) Comparative osteology of the penguin-like mid-Cenozoic Plotopteridae and the earliest true fossil penguins, with comments on the origins of wing-propelled diving. Journal of Zoological Systematics and Evolutionary Research, 59: 264-276. https://doi.org/10.1111/jzs.12400

Mayr G, Smith T (2012) Phylogenetic affinities and taxonomy of the Oligocene Diomedeoididae, and the basal divergences amongst extant procellariiform birds. Zoological Journal of the Linnean Society 166: 854-875. https://doi.org/10.1111/j.1096-3642.2012.00858.x

McCormack JE, Harvey MG, Faircloth BC, Crawford NG, Glenn TC, Brumfield RT (2013) A phylogeny of birds based on over 1,500 loci collected by target enrichment and high-throughput sequencing. PLoS ONE 8(1): e54848. https://doi.org/10.1371/journal.pone.0054848

Olson SL, Hasegawa Y (1979) Fossil counterparts of giant penguins from the North Pacific. Science 206: 688-689. https://doi.org/10.1126/science.206.4419.688

Padian K, Hutchinson JR, Holtz TR (1999) Phylogenetic definitions and nomenclature of the major taxonomic categories of the carnivorous Dinosauria (Theropoda). Journal of Vertebrate Paleontology 19: 6980. https://doi.org/10.1080/02724634.1999.10011123

Prum RO, Berv JS, Dornburg A, Field DJ, Townsend JP, Lemmon EM, Lemmon AR (2015) A comprehensive phylogeny of birds (Aves) using targeted next-generation DNA sequencing. Nature 526: 569573. https://doi.org/10.1038/nature15697

Reddy S, Kimball RT, Pandey A, Hosner PA, Braun MJ, Hackett SJ, Han K-L, Harshman J, Huddleston CJ, Kingston S, Marks BD, Miglia KJ, Moore WS, Sheldon FH, Witt CC, Yuri T, Braun EL (2017) Why do phylogenomic data sets yield conflicting trees? Data type influences the avian tree of life more than taxon sampling. Systematic Biology 66: 857-879. https://doi.org/10.1093/sysbio/syx041

Rowe T (1987) Definitions and diagnosis in the phylogenetic system. Systematic Zoology 36: 208-211. https://doi.org/10.2307/2413270 
Sangster G (2005a) A name for the clade formed by owlet-nightjars, swifts and hummingbirds (Aves). Zootaxa 799: 1-6. https://doi.org/ 10.11646/zootaxa.799.1.1

Sangster G (2005b) A name for the flamingo-grebe clade. Ibis 147: 612615. https://doi.org/10.1111/j.1474-919x.2005.00432.x

Storer RW (1971) Classification of birds. Avian Biology 1: 1-18.

Suh A, Paus M, Kiefmann M, Churakov G, Franke FA, Brosius J, Kriegs JO, Schmitz J (2011) Mesozoic retroposons reveal parrots as the closest living relatives of passerine birds. Nature Communications 2: 443. https://doi.org/10.1038/ncomms 1448
Suh A, Smeds L, Ellegren H (2015) The dynamics of incomplete lineage sorting across the ancient adaptive radiation of neoavian birds. PLoS Biology 13(8): e1002224. https://doi.org/10.1371/journal.pbio. 1002224

Yuri T, Kimball RT, Harshman J, Bowie RCK, Braun MJ, Chojnowski JL, Han K-L, Hackett SJ, Huddleston CJ, Moore WS, Reddy S, Sheldon FH, Steadman DW, Witt CC, Braun EL (2013) Parsimony and model-based analyses of indels in avian nuclear genes reveal congruent and incongruent phylogenetic signals. Biology 2: 419444. https://doi.org/10.3390/biology2010419 